\title{
Evaluation of self-esteem among homosexuals in the southern region of the state of Santa Catarina, Brazil
}

\author{
Avaliação da autoestima de gays do sul de Santa Catarina, Brasil
}

Tiago José Canali ${ }^{1}$

Sylvia Marina Soares de Oliveira ${ }^{1}$

Deivid Montero Reduit ${ }^{1}$

Daniele Botelho Vinholes ${ }^{1}$

Viviane Pessi Feldens ${ }^{1}$

${ }^{1}$ Departamento de Ciências Biológicas e da Saúde e de Ciências Sociais Aplicadas, Universidade do Sul de Santa Catarina. Av. José Acácio Moreira 787, Dehon. 88704-900 Tubarão SC Brasil.

dvinholes@terra.com.br
Abstract This study seeks to evaluate self-esteem in homosexuals from southern Santa Catarina and relate it to several variables such as gender, age, bullying and psychiatric treatment. Participants were selected using the "Snowball" technique. The Rosenberg self-esteem scale was used for self-esteem assessment with subsequent comparison with other variables. A total of 403 individuals were interviewed, including 310 males with a mean age of 24.02. Most of the population studied (80.9\%) had high self-esteem, with a mean score of 5.55 on the Rosenberg scale. Individuals who had only studied up to primary school level, were unemployed, evangelicals, with a history of psychotherapeutic and psychiatric treatment, or who had been subjected to bullying in the last year and those who wished to change their sexual orientation, had significantly lower self-esteem than the others. 114 people had used psychotropic drugs, $47.58 \%$ of which were benzodiazepine-based, primarily Clonazepam (27.58\%). Most of this population had high self-esteem. There was a difference between some categories of the variables studied, however, all averages corresponded to high self-esteem on the Rosenberg scale. Benzodiazepines were the psychotropic drugs most often used by the individuals in this study.

Key words Homosexuality, Self-esteem, Mental health, Bullying
Resumo O artigo tem por objetivo avaliar a autoestima em homossexuais do sul de Santa Catarina e sua relação com várias variáveis como sexo, idade, bullying e tratamento psiquiátrico. Participantes foram selecionados utilizando a técnica "Bola de neve". A escala de Rosenberg foi utilizada para avaliação da autoestima e subsequente comparação com outras variáveis. Ao todo, 403 indivíduos foram entrevistados, sendo 310 homens com média de idade de 24,02 anos. A maioria da amostra estudada (80,9\%) tinha alta autoestima, com um escore médio na Escala de Rosenberg de 5,55 pontos. Indivíduos que estudaram até o ensino fundamental, desempregados, evangélicos, com tratamento psicoterápico e psiquiátrico prévio, que sofreram bullying no último ano e aqueles que gostariam de mudar sua orientação sexual, tiveram significativamente mais baixa autoestima. Usaram drogas psicotrópicas 114 indivíduos, sendo 47,58\% benzodiazepínicos, com ênfase para o Clonazepam (27,58\%). A maioria da amostra tinha alta autoestima. Houve uma diferença entre algumas categorias das variáveis estudadas, entretanto, todas as médias corresponderam à alta autoestima na Escala de Rosenberg. Benzodiazepinicos foram as drogas psicotrópicas mais utilizadas pelos indivíduos neste estudo.

Palavras-chave Homossexualidade, Autoestima, Saúde mental, Bullying 


\section{Introduction}

Homosexuality is as old as heterosexuality, and throughout history has been approached from various angles. Different cultures and civilizations have always found a way to reveal its existence through legends, myths, stories and scenarios. A good example is the ancient Greece, where the practice of homosexuality had been part of the routine of the gods and heroes, seen as a natural necessity, restricted to cults environments and being considered a real privilege for the well-born. In Rome, it had not been much different. Same-sex relations were regarded with natural origin, that is, like any other relationship, such as the relationship between couples or between a master and a slave ${ }^{1}$.

The homosexual experience has already been treated as a disease, curse, and disturbance. The International Classification of Diseases (ICD), that has been created more than a century, identified the "homosexuality" as a sexual disease. Only in 1995, on the 10th revision of ICD-10, sexual orientation by itself has no longer been considered a disorder. The suffix "ismo", (in Portuguese: sexualismo), which means a disease, has been replaced by the suffix "dade", (in Portuguese: sexualidade), which means "way of being".

Homosexuality, today, must be understood as the natural expression of human sexuality by people of the same sex with emotional involvement in relationships and not just sex with the same genders ${ }^{1}$. It should be seen as a relationship that involves a range of phenomena, which involve biological and social ${ }^{2}$ aspects.

Unfortunately, many environments are characterized as places of oppression, prejudice and discrimination, besides physical and mental violence, which are subjected youth and adult gays. Such situations have been termed by the term bullying, an English term that refers to aggression, humiliation, threats, taunts, which are performed by one or more individuals, causing pain and distress, with the objective of intimidating or harming another person, which commonly has no ability or capacity to defend ${ }^{3}$ oneself. In general, bullying is performed in a relationship of unequal forces or power ${ }^{3}$.

Many gays have already been living in difficult situations, which collaborate to internalize homophobia, denial, self-blame and self-hatred, which may be aggravated by the omission of family, school community, society, State ${ }^{3}$. Currently the bias takes a more subtle character because of the prevailing social norms, which oppress discriminatory $y^{4,5}$ behavior.
With that information, it appears that gays tend to have more episodes of mental disorders, and therefore a greater quest for psychotherapy and / or psychopharmacological ${ }^{6}$ treatment. Another interesting aspect is focused on the fact that individuals who have not taken on a full orientation and gay identity tend to have more psychological distress, lower psychosocial well-being and even be ashamed of their orientation.

Given the importance of this scenario, the Ministry of Health has supported programs in areas of strengthening networks, has developed communications campaigns and actions to the public visibility of gays, lesbians, bisexuals and transgender (GLBT) as a strategy for promoting health and promoting participation of the GLBT movement in advisory bodies. Such measures have aimed the implementation of national policies to combat, especially homophobia ${ }^{3,7,8}$.

Gays often have conflicts during the formation of sexual identity, since they share the same characteristics intrinsic to genders, male and female 9 . In this context the importance of self-esteem has been emphasized, which has a remarkable relationship with the formation of gays ${ }^{10}$ personality and mental health.

Self-esteem is related to how one respects oneself, how one feels, being able to exert influence in a range of attitudes, from food to the way that your body has been seen ${ }^{11}$. By virtue of many obstacles encountered in gay lives, as physical threats, experience in conservative environment, abuses and imposition of values and functions pre-set by society, self-esteem in gays tend to be lower when compared to heterosexuals ${ }^{12-15}$. In this sense, the habit of thinking negatively about your own body has been associated with the genesis of psychological distress and impaired mental health ${ }^{16}$.

It is observable that low self-esteem affects the development and quality of life of gays, in all ages, which explains the importance of this study that relates several variables to this component. For all these reasons and the lack of national literature on the subject, this paper aims to evaluate self-esteem in gays in the region of southern Santa Catarina and assess the possible association with sociodemographics and cultural variables.

\section{Methods}

A cross-sectional study has been performed. People who have been interviewed have self-defined gays, being minimum age 18 , living in cities of the 
southern state of Santa Catarina, between August 2011 and March 2012, through non-probability sampling, formed by convenience. This region comprises 43 municipalities with an estimated population of 900,000 inhabitants, including three macro-regions, the association of municipalities of Laguna (Amurel), with head office in Tubarão, the Association of Municipalities of the Coal Region (AMREC), with head-office in Criciúma and the Association of Municipalities of Southernmost Santa Catarina (AMESC), with head-office in Araranguá ${ }^{17}$. The ones who had significant doubts regarding sexual orientation and not agreed to participate in the study have been excluded from the research ${ }^{18}$.

Studied participants have been interviewed using the "snowball"19 technique. In this technique, initially, a small group of individuals, previously known by the author of this paper and compatible with the inclusion criteria, have been subjected to the questionnaire. Subsequently, these respondents have been asked to indicate others of their socio-cultural environment to also be evaluated. Those have also been able to indicate others, which also indicated others and so forth. By indications, home visits or meetings have previously been scheduled.

After clarification of the technical studies and the "snowball" technique, the signature on the Term of Consent has been requested, and after the signing, the questionnaire related to this paper has been applied, ensuring confidentiality to the respondents regarding the data collected.

A questionnaire consisting of some socio-demographic and socio-cultural variables and the Rosenberg Self-Esteem Scale has been used. The socio-demographic and socio-cultural variables included gender, age (up to 20 years old, 21-30, 31 or older), education (elementary school, secondary school, higher education), occupation (student, employed, unemployed), religion (atheist, catholic, spiritualism, evangelical or another), therapy with psychologist, psychiatric treatment, use of psychotropic bullying in childhood and in the last 12 months, change in sexual orientation.

The questionnaire was through self-filled. This validated scale evaluates global self-esteem through self-report ${ }^{20}$. It was established in 1965 by M. Rosenberg ${ }^{21}$ and adapted for Brazil in 2004 by G.M. Dini et al. ${ }^{20}$. It consists of ten (10) statements related to general feelings of self-esteem. Items can be marked with four responses, ranging from "strongly agree" to "strongly disagree". Five questions assess one's positive feelings about oneself. To score the responses, the five items ex- pressing negative feelings have inverted values and then add up these values to the other five items, totaling a single value for the scale, corresponding to the responses of the ten items. Thus, the final score scale may range from 0 (best self-esteem) to 30 (worst esteem). In this sense, the higher the score is on the scale, the worst self-esteem is, and the lower, the higher self-esteem ${ }^{19}$. Rosenberg scale has been opted because it specifically addresses self-esteem and is available in the national literature; besides it has advantages as the ability to detect small changes in self-esteem, has psychometric properties, is short and easy to use and understand .

The project has been approved by the Ethics and Research Committee of the Institution under the number that the Free and Clarified Consent Term has been used for all interviews. After approval by the Ethics and Research Committee of the Institution, the data were collected for the related research.

The researchers have pledged to preserve the information contained in the records, ensuring confidentiality and privacy of the researched people. Moreover, they have also pledged to observe all the ethical requirements established by Resolution CNS 196/9622.

The typing of data has been performed by the author of this paper on Epinfo Program version 3.5.1. The statistical analysis has been performed using SPSS version 18.0. For descriptive analysis of data measures of frequency has been used and mean with standard deviation. For association test the chi-square test has been used, and ANOVA to compare means. For this study the value of significance $\mathrm{p}<0.05$ has been adopted.

\section{Results}

In total 403 interviews have been performed, with no loss. Most of the interviewees have lived in the region of Amurel, macro-region that has had $n=207(51.4 \%)$, predominantly to the city of Tubarão, which had $\mathrm{n}=133$. The AMREC region has had $n=130(32.3 \%)$, with a preponderance of the city of Criciúma, with 98 persons. The macro-region of AMESC displayed $n=66$ (16.4\%), most of the city of Araranguá, with $\mathrm{n}=55$. The mean age has 24.02, ranging from 18 to 50 years.

This research has faced with predominantly male individuals (76.9\%), aged from 21 to 30 years $(54.6 \%)$, with higher education (complete or incomplete) (49.1\%), Catholics (49.4\%), who had never held psychotherapy $(53.6 \%)$, or 
psychiatric treatment $(82.4 \%)$ and never used psychotropic drugs (71.7\%). Also there was a predominance of individuals who experienced bullying during childhood (54.1\%), but has not dealt with this situation over the past 12 months $(77.9 \%)$ and do not yearn for a change in its orientation to heterosexuality $(72,7 \%)$ (Table 1$)$.

Regarding Rosenberg self-esteem scale, 326 individuals $(80.9 \%)$ have had self-esteem score equal to or less than 10, indicating a high level.
This situation has repeated in all variables, with a mean of 5.55. The mode found was 0 (zero), which has appeared 78 times, indicating a high prevalence of maximum level of self-esteem. The distribution of the mean and standard deviation (SD) of self-esteem as variables of this study is shown in Table 1.

The use of psychotropic drugs has been reported by 114 patients (28.3\%) with 145 quotes, since many people have reported more than one

Table 1. Distribution of variables according to frequency, prevalence, mean of Rosenberg Self-Esteem Scale and corresponding standard deviation.

\begin{tabular}{|c|c|c|c|c|c|}
\hline Distribution of variables & $\mathbf{N}$ & $\%$ & Mean & SD & Value of $p$ \\
\hline Gender & & & & & 0.208 \\
\hline Female & 93 & 23.1 & 6.18 & 5.45 & \\
\hline Male & 310 & 76.9 & 5.36 & 5.46 & \\
\hline Age & & & & & 0.090 \\
\hline Up to 20 years old & 135 & 33.5 & 6.35 & 5.49 & \\
\hline $21-30$ years old & 220 & 54.6 & 5.26 & 5.44 & \\
\hline 31 or older & 48 & 11.9 & 4.67 & 5.46 & \\
\hline Education & & & & & $0.001^{*}$ \\
\hline Elementary School & 28 & 6.9 & 9.25 & 6.43 & \\
\hline Secondary School & 177 & 43.9 & 5.86 & 5.51 & \\
\hline Higher Education & 198 & 49.1 & 4.76 & 5.05 & \\
\hline Occupation & & & & & $0.021^{*}$ \\
\hline Student & 61 & 15.1 & 7.07 & 5.25 & \\
\hline Employed & 296 & 73.4 & 5.11 & 5.53 & \\
\hline Unemployed & 46 & 11.4 & 6.39 & 4.97 & \\
\hline Religion & & & & & $0.024^{*}$ \\
\hline Atheist & 92 & 22.8 & 5.92 & 5.55 & \\
\hline Catholic & 199 & 49.4 & 5.33 & 5.11 & \\
\hline Spiritualism & 33 & 8.2 & 3.94 & 4.29 & \\
\hline Evangelical & 28 & 6.9 & 8.36 & 7.01 & \\
\hline Another & 51 & 12.7 & 5.29 & 5.97 & \\
\hline Therapy with psychologist & & & & & $0.007^{*}$ \\
\hline Yes & 187 & 46.4 & 6.34 & 6.01 & \\
\hline No & 216 & 53.6 & 4.87 & 4.85 & \\
\hline Psychiatric treatment & & & & & $0.004^{*}$ \\
\hline Yes & 71 & 17.6 & 7.25 & 6.79 & \\
\hline No & 332 & 82.4 & 5.19 & 5.07 & \\
\hline Use of psychotropics & & & & & 0.165 \\
\hline Yes & 114 & 28.3 & 6.15 & 6.32 & \\
\hline No & 289 & 71.7 & 5.31 & 5.07 & \\
\hline Bullying in childhood & & & & & 0.121 \\
\hline Yes & 218 & 54.1 & 5.09 & 5.34 & \\
\hline No & 185 & 45.9 & 5.94 & 5.54 & \\
\hline Bullying in the last 12 months & & & & & $0.005^{*}$ \\
\hline Yes & 89 & 22.1 & 6.97 & 5.49 & \\
\hline No & 314 & 77.9 & 5.15 & 5.39 & \\
\hline Would change his/her sexual orientation & & & & & $0.001^{*}$ \\
\hline Yes & 110 & 27.3 & 7.51 & 6.62 & \\
\hline No & 293 & 72.7 & 4.81 & 4.76 & \\
\hline
\end{tabular}


Self-esteem has been studied and considered an important indicator of mental health and, along with the theme "quality of life", has attracted the attention of professionals and scholars in various fields ${ }^{23}$. A multicenter survey, covering 14 countries, concluded that the quality of life is strongly related to psychological function, and among the various psychological aspects the one of greatest importance has been self-esteem ${ }^{24}$.

When self-esteem is affected, it may reflect symptoms of anxiety, shame, difficulty to make friends and have a conversation ${ }^{6,21}$. In addition, it has been associated passivity on discussions and little aptitude for leadership, low interest in public issues and high sensitivity to criticism ${ }^{21}$.

It has been notable high prevalence of individuals in the region of Amurel, especially the city of Tubarão. This result has already been expected because of the choice of methodology "snowball", a not random procedure, therefore, subject to selection bias, since, in most cases, people of the same social circle are indicated. This technique has been adopted because gays are a population difficult to reach, mainly because of the stigma in this society and the existing prejudice throughout the country. Thus there was no need for exposure of individuals to the whole community, but only among individuals previously known and with similar characteristics.

Table 2. Used psychotropics distributed according to its frequency and prevalence.

\begin{tabular}{lcc}
\hline \multicolumn{1}{c}{ Psychotropic } & Frequency & Valid Percentage \\
\hline Clonazepam & 40 & 27.6 \\
Diazepam & 14 & 9.7 \\
Paroxetine & 10 & 6.9 \\
Bromazepam & 09 & 6.2 \\
Lithium Carbonate & 08 & 5.5 \\
Fluoxetine & 05 & 3.4 \\
Alprazolam & 04 & 2.8 \\
Others & 27 & 18.6 \\
Don't remember & 28 & 19.3 \\
Total & $\mathbf{1 4 5}$ & $\mathbf{1 0 0}$ \\
\hline
\end{tabular}

The present study has shown high self-esteem in all variables, with more than $80 \%$ of individuals with scores on the Rosenberg scale of less than or equal to 10. It has been concluded that there has been no significant difference in comparing the degree of self-esteem and the variables gender and age, only a trend to higher self-esteem among individuals aged 30 years or more (0.090). However, a study of D'Augelli et al. ${ }^{25}$ showed improved self-esteem with advancing age.

These results are opposed to a study with gays in the city of Tel-Aviv, Israel ${ }^{13}$, which compared the self-esteem among 109 heterosexual and 90 homosexual indicating low self-esteem among the latter ones, according to the Rosenberg scale. This result may be explained due to repressive and conservative social culture and religious matters in that Asian country. In connection with this Israeli study, age has not had statistically significant variation, confirming findings of this study. On the other hand, a home study in Cana$\mathrm{da}^{11}$ has verified that the more they become older, more self-esteem decreases, which has not been confirmed in this study, it has shown a reverse trend, that self-esteem increased later in life.

Regarding gender, the results contrast with findings of a study among employees of a foundation of higher education in Pouso Alegre, Minas Gerais ${ }^{26}$, it has shown significantly lower self-esteem among females. Another study with employees of a university of Sao Paulo ${ }^{27}$, has examined that females have shown more personal, social and work stress; and more psychosocial risk factors, meaning lower rates of mental health than men, and showing greater risk for physical illness and / or mental, favoring the emergence of feelings of inadequacy and low self-esteem, theory not consolidated by this research. It is noteworthy, that for this variable studies with individuals of any sexual orientation have been used for discussion. In another study in the Dutch population aged 18-64 showed that the sexuality has influence in the quality of life in male, but not in female ${ }^{28}$.

The schooling has presented significant relation with self-esteem $(p=0.001)$, with higher scores on the scale among individuals who only finished elementary school, partial or total, indicating that they have lower self-esteem. Similar results have been found in a study of pregnant women of Pelotas, Rio Grande do Sul ${ }^{29}$ with high self-esteem among women with higher education, complete or in progress. This result, in studies with different populations, may be explained by the fact that people with higher edu- 
cation generally have higher achievement, higher socioeconomic status, greater access to leisure facilities, cultural activities, among other factors, regardless sexual orientation.

Regarding occupation, gays with a paid job has had significantly higher self-esteem ( $\mathrm{p}=$ 0.021) compared to students and unemployed ones. A study in France has shown similar results, indicating that individuals with a regular income have higher self-esteem in relation to the unemployed $^{30}$. This result may be due to the fact that an individual income may allow a higher power of consumption and greater access to achievements and accomplishments, even if in material scope.

In this study, the religion factor has had a significant value $(p=0.024)$, with intense emphasis on low self-esteem among evangelicals. This result may be explained by the fact that evangelical churches are still very conservative, with little open on controversial issues such as homosexuality. In addition, individuals who are openly from LGBT population can only participate in evangelical religion as visitors, they may not be effective members or occupy higher positions in the church. While the above study of Pouso Alegre, Minas Gerais ${ }^{26}$, has not shown significant degree relevant to religion factor $(\mathrm{p}=0.458)$.

The present study has revealed a significant relationship between the presence of low self-esteem and a previous psychotherapy and administration of psychiatric treatment. Similar results have been found in a study conducted in São Paulo ${ }^{6}$, which has shown a tendency of homosexual group present more mental disorders and look significantly more for psychotherapy. One reason for this seek would be a shame and rejection of one's sexual orientation ${ }^{6}$, factors that cause psychological distress and decreased self-esteem, since it has been studied and considered an important indicator of mental health. An Indian ${ }^{31}$ study, has shown similar results, and suggests that this reality is even more present in India, because homosexuality there is a crime punishable by imprisonment. Such theories have been confirmed in this study because gays are not satisfied with their condition and would like to change their orientation to heterosexuality have had significantly lower self-esteem ( $p=0.001$ ), perhaps because they are ashamed and have no acceptance of their sexual orientation.

The suffering of bullying in childhood and / or adolescence was not significantly associated with self-esteem $(\mathrm{p}=0.121)$. One explanation for this situation has been exposed by Ceará e
Dalgalarrondo ${ }^{6}$, indicating that in adulthood, most gays can overcome the feeling of shame, and achieve a greater capacity to deal with discrimination, mainly due to greater life experience, during which these individuals might have developed a better repertoire of dealing with adverse situations. But recent bullying (within the last 12 months) has presented significant association with decreased of self-esteem ( $\mathrm{p}=$ 0.005 ), perhaps because it has been a recent suffering, without the existence of sufficient period of time to overcome the occurrence partial or total of the situation. A study of gays from the United States of America ${ }^{16}$ has shown an association among bullying suffering with depressive symptoms, learning difficulties, school dropout and low self-esteem. In another U.S. ${ }^{32}$ study, these findings have also obtained and the prevalence of bullying suffering in childhood of the LGBT population has been $85 \%$, higher than the value found in this study, which has been close to $55 \%$.

It has not been found in world literature studies that have specified psychotropic specifically used by gays. In this paper, it has been noted that 114 individuals who responded to take or have taken psychotropic drugs, only 53 (46.49\%) have already been to a psychiatrist, it may be inferred that maybe the drugs have been prescribed by non-specialized doctors or have been obtained by other forms. A study on chronic users of benzodiazepines in Valencia, Spain ${ }^{33}$, the general practitioner has been the regular prescriber in almost $100 \%$ of cases, and the fact that they are close friends of doctors, has helped in getting the prescription. In another survey, with students from public schools in ten Brazilian capitals $^{34}, 5.8 \%$ of the surveyed ones said they have taken tranquilizers without a prescription. A study among chronic users of benzodiazepines performed in São Paulo ${ }^{35}$ has revealed that such medicines are used primarily for resolution or relief of sleep disorders and anxiety disorders, which has its genesis related to low self-esteem ${ }^{6,21}$. Thus, it has been inferred that perhaps these are the most frequent pathologies among gays, users of benzodiazepines in this study.

In a systematic review it was evidenced that lesbian, gays and bisexual people are at higher risk of mental disorder, suicide ideation, and substance misuse than heterosexual people ${ }^{36}$.

Because self-esteem has been studied and considered an important indicator of mental health and strongly related to the quality of life of individuals, further studies with specific groups such as LGBT are stimulated, which has 
a nationwide shortage of surveys. Thus, it is indicated a research between self-esteem and several variables, searching for relations and reasons for these findings in larger cities and larger geographic areas.

As limitations of this study could cited the convenience sampling that could indicates a possible bias and a limitation in the extrapolations of the results. The questionnaire used to assess self-esteem was validate in patients submitted to plastic surgery, so the high self-esteem levels in this study could be due this difference in target population.

\section{Collaborations}

TJ Canali, SMS Oliveira and DM Reduit participated in data collection. DB Vinholes and VP Feldens participated in the Project conduction and analysis and interpretation of data.

\section{Conclusion}

Most of the studied population (80.9\%) has presented high self-esteem. Individuals who have studied only up to elementary school, unemployed, evangelicals with prior psychotherapy, previous psychiatric treatment, that have faced a situation of bullying in the last year and would like to change their orientation have lower self-esteem than the others. Benzodiazepines are the most widely used psychoactive drugs by the population under study, with emphasis on the Clonazepam.

\section{References}

1. Dias MB. União homoafetiva: o preconceito \& a justiça. $4^{\text {a }}$ ed. rev., atual. e ampl. São Paulo: Revista dos Tribunais; 2009

2. Oltramari LC. Política e sexualidade: notas sobre o combate ao preconceito contra os homossexuais. Psicologia \& Sociedade 2010; 22(3):608-661.

3. Junqueira RD. Diversidade sexual na educação: problematizações sobre a homofobia nas escolas. Brasília: Unesco; 2009.

4. Fleury ARD, Torres ARR. Análise psicossocial do preconceito contra homossexuais. Estudos de Psicologia 2007; 24(4):475-486.

5. Pereira C, Torres ARR, Almeida ST. Um Estudo do Preconceito na Perspectiva das Representações Sociais: Análise da Influência de um Discurso Justificador da Discriminação no Preconceito Racial. Psicologia: Reflexão e Crítica 2003; 16(1):95-107.

6. Ceará AT, Dalgalarrondo P. Transtornos mentais, qualidade de vida e identidade em homossexuais na maturidade e velhice. Revista de Psiquiatria Clínica 2010; 37(3):118-123.

7. Brasil. Ministério da Saúde. Saúde da população de gays, lésbicas, bissexuais, travestis e transexuais. Rev Saude Publica 2008; 42(3):570-573.

8. Chesir-Teran D, Hughes D. Heterosexism in High School and Victimization Among Lesbian, Gay, Bisexual, and Questioning Students. J Youth Adolescence 2009; 38(7):963-997.

9. Zoccali R, Muscatello MR, Bruno A, Serrano D, Campolo D, Pandolfo G, Cedro C, La Torre D, Meduri M. Gender Role Identity in a Sample of Italian Male Gays. Journal of Homosexuality 2008; 55(2):265-273.

10. Pereira H, Leal IP. A identidade (homo)sexual e os seus determinantes: Implicações para a saúde. Análise Psicológica 2005; 3(XXIII):315-322. 
11. McMullin JA, Cairney J. Self-esteem and the intersection of age, class, and gender. Journal of Aging Studies 2004; 18(1):75-90.

12. Cohn TJ, Hastings SL. Resilience Among Rural Lesbian Youth. Journal of Lesbian Studies 2010; 14(1):71-79.

13. Rubinstein G. Narcissism and Self-Esteem Among Homosexual and Heterosexual Male Students. J Sex Marital Ther 2010; 36(1):24-34.

14. Łosiak J. Body image in homosexual persons. Psychiatr Pol 2009; 43(1):99-107.

15. Blais M, Gervais J, Hebert M. Homofobia internalizada como mediador parcial bullying homofóbico e autoestima entre jovens de minorias sexuais em Quebec (Canadá). Cien Saude Colet 2014; 19(3):727-735.

16. Birkett M, Espelage DL, Koenig B. LGB and questioning students in schools: the moderating effects of homophobic bullying and school climate on negative outcomes. J Youth Adolesc 2009; 38(7):989-1000.

17. Instituto Brasileiro de Geografia e Estatística (IBGE). Censo Demográfico 2010. [acessado 2011 maio 4]. Disponível em: http://www.ibge.gov.br/home/estatistica/ populacao/censo2010/default.shtm

18. Freire T, Tavares D. Influência da autoestima, da regulação emocional e do gênero no bem estar subjetivo e psicológico de adolescentes. Rev Psiquiatr Clin 2011; 38(5):184-188.

19. Biernacki P, Waldorf D. Snowball sampling: problems and techniques of chain referral sampling. Sociol Methods Res 2002; 10(2):141-163.

20. Dini GM, Quaresma MR, Ferreira LM. Adaptação Cultural e Validação da Versão Brasileira da Escala de Auto-estima de Rosenberg. Revista Brasileira de Cirurgia Plástica 2004; 19(1):41-52.

21. Rosenberg M. Society and the adolescent self-image. Princeton: Princeton University Press; 1965.

22. Brasil. Ministério da Saúde (MS). Conselho Nacional de Saúde. Resolução no 196 de 10 de outubro de 1996. Diretrizes e Normas Regulamentadoras de Pesquisas Envolvendo Seres Humanos. Diário Oficial da União 1996; 16 out.

23. Andrade D, Angerami ELS. A auto-estima em adolescentes com e sem fissuras de lábio e/ou de palato. Revista Latino-Americana de Enfermagem 2001; 9(6):37-41.

24. Power M, Bullinger M, Harper A. The world health organization WHOQOL-100: tests of the universality of quality of life in 15 different cultural groups worldswide. Health psychology 1999; 18(5):495-505.

25. D'Augelli AR, Grossman AH, Hershberger SL, O'Connell TS. Aspects of mental health among older lesbian, gay, and bisexual adults. Aging ment health 2001; 5(2):145-158.

26. Carvalho MIB. Escala de Auto-Estima Rosenberg UNIFESP-EPM em Funcionários da Fundação de Ensino Superior do Vale do Sapucaí em Pouso Alegre - MG [dissertação]. São Paulo: UFSP; 2006.
27. Areias MEQ, Guimarães LAM. Gênero e estresse em trabalhadores de uma Universidade Pública do Estado de São Paulo. Psicologia em Estudo 2004; 9(2):255-262.

28. Sandfort TG, de Graaf R, Bijl RV. Same-sex sexuality and quality of life: findings from the Netherlands Mental Health Survey and Incidence Study. Arch Sex Behav 2003; 32(1):15-22.

29. Dias MS, Silva RA, Souza LDM, Lima RC, Pinheiro RT, Moraes IGS. Auto-estima e fatores associados em gestantes da cidade de Pelotas, Rio Grande do Sul, Brasil. Cad Saude Publica 2008; 24(12):2787-2797.

30. Vézina M, Derriennic F, Monfort C. The impact of job strain on social isolation: a longitudinal analysis of French workers. Social Science and Medicine. 2004; 59(1):29-30

31. Agoramoorthy G, Hsu MJ. India's homosexual discrimination and health consequences. Rev Saude Publica 2007; 41(4):657-660.

32. Hightow-Weidman LB, Phillips G, Jones KC, Outlaw AY, Fields SD, Smith JC, YMSM of Color SPNS Initiative Study Group. Racial and sexual identity-related maltreatment among minority YMSM: prevalence, perceptions, and the association with emotional distress. AIDS Patient Care STDS. 2011; 25(1)39-45.

33. Sobrecases BS, Gonzalez AL, Martínez FJ, Varela MMS. Sociodemographic characteristics of female habitual benzodiazepine consumers in the catchment area of a health care center. Scand J Soc Med 1997; 25(3):176179.

34. Galduróz JCF, Noto AR, Carlini EA. IV Levantamento sobre uso de drogas entre estudantes de $1^{\circ} \mathrm{e} 2^{\circ}$ graus de 10 capitais brasileiras - 1997. São Paulo: UNIFESP; 1997.

35. Orlandi P, Noto AR. Uso indevido de benzodiazepínicos: um estudo com informantes-chave no município de São Paulo. Rev. Latino-Am. Enfermagem 2005; 13(N. Esp.):896-902.

36. King M, Semlyen J, Tai SS, Killapsy H, Osborn D, Popelyuk D, Nazareth I. A systematic review of mental disorder, suicide, and deliberate self-harm in lesbian, gay and bisexual people. BMC Psychiatric 2008; 8:70.

Artigo apresentado em 03/07/2013

Aprovado em 27/08/2013

Versão final apresentada em 03/09/2013 